\title{
Organ-specific and non-organ-specific autoantibodies in children and young adults with autoimmune polyendocrinopathy-candidiasis-ectodermal dystrophy (APECED)
}

\author{
Roberto Perniola ${ }^{1}$, Alberto Falorni ${ }^{2}$, Maria Grazia Clemente ${ }^{3}$, Francesca Forini ${ }^{2}$, Elisa Accogli ${ }^{4}$ and \\ Giambattista Lobreglio ${ }^{4}$ \\ ${ }^{1}$ Paediatric and ${ }^{4}$ Laboratory Medicine Units, Vito Fazzi Regional Hospital, Lecce, Italy, ${ }^{2}$ Department of Internal Medicine and Endocrine and Metabolic \\ Sciences, University of Perugia, Perugia, Italy and ${ }^{3}$ Department of Biomedical Sciences and Biotechnologies, University of Cagliari, Cagliari, Italy \\ (Correspondence should be addressed to Roberto Perniola, Via Cerrate Casale 6, I-73100 Lecce, Italy; Email: rperniola@hotmail.com)
}

\begin{abstract}
Objective: The aim of the study was to assess the complex of autoantibodies which can be detected in patients with autoimmune polyendocrinopathy-candidiasis-ectodermal dystrophy (APECED), a rare autosomal recessive disease in which the extent of autoimmunity is still unknown.

Design: Antibodies (A) to parathyroid glands, adrenal cortex (AC-A), ovary and testis (steroid cell antibodies, SC-A), pancreatic islet cells (IC-A), gastric parietal cells, and non-organ-specific antigens were investigated in 11 APECED patients living in the Salento region of southern Italy. Further measurements included antibodies to cytochrome P450 (CYP) enzymes: cholesterol side-chain cleavage enzyme (CYP11A), 21-hydroxylase (CYP21) and 17 $\alpha$-hydroxylase (CYP17); and to glutamic acid decarboxylase 65-kDa isoform (GAD65), tyrosine phosphatase-like protein IA2, thyroglobulin (TG), thyroperoxidase (TPO), thyrotropin receptor, liver CYP enzymes and intrinsic factor.

Methods: Antibodies to organs and subcellular fractions were detected by immunofluorescence. Radiobinding, immunoradiometric, and immunoblotting assays were used for the other measurements. Results: AC-A and SC-A were positive in all sera; among antibodies to adrenal CYP enzymes, only CYP21-A were present in all the patients with Addison's disease of short-medium duration ( $<15$ years). Of three patients with Addison's disease of long duration ( $>15$ years), two tested positive for antibodies to all three CYP enzymes, and the other for only CYP11A-A. In all sera CYP11A-A and/or CYP17-A were found. Two patients tested positive for both IC-A and GAD65-A, one for both IC-A and IA2-A, and one for GAD65-A; the fasting C-peptide assay showed no statistical difference between these four subjects and the others. All four hypothyroid patients were positive for TPO-A, while two of them were positive and two were negative for TG-A; two euthyroid subjects had positivity for TG-A. Liver-kidney microsomal antibodies reacting against the CYP2A 6 were detected in two patients with autoimmune hepatitis. All but one sera contained anti-nuclear antibodies at a titre ranging between 1:20 and 1:80; however, only two patients had a connective tissue disease (Sjögren's syndrome).

Conclusions: Several autoantibodies may be detected in any APECED patient. Our data confirm that CYP21-A and TPO-A are major autoantibodies involved in APECED-associated Addison's disease and hypothyroidism respectively, while CYP11A-A and CYP17-A correlate with positivity for SC-A. Markers of islet cell autoimmunity are frequent, but prevalence and modalities of progression to overt $\beta$-cell failure have to be clarified. Low-titre non-organ-specific autoantibodies are a feature of autoimmunity in APECED, but their role has yet to be fully explained.
\end{abstract}

European Journal of Endocrinology 143 497-503

\section{Introduction}

Autoimmune polyglandular syndrome type 1 (APS 1), by now referred to as autoimmune polyendocrinopathycandidiasis-ectodermal dystrophy (APECED; OMIM 240300), is a rare autosomal recessive disease which maps to chromosome 21q22.3. A novel gene, defined AIRE (for AutoImmune REgulator), has been isolated from this region: the resulting 545 amino acid product contains sequences suggestive of a transcription factor, including two plant homeodomain-type zinc-finger (PHD-finger) motifs, a proline-rich region and three LXXLL motifs (1). Chronic mucocutaneous candidiasis (CMC), hypoparathyroidism and Addison's disease represent the classic triad of APECED; hypogonadism, type 1 (insulin-dependent) diabetes mellitus (IDDM), 
hypothyroidism, gastric parietal cell failure, autoimmune hepatitis (AIH) and several ectodermal dystrophies have been described in a varying percentage of cases $(2,3)$.

The main markers of autoimmunity in APECED patients have recently been identified (4): three cytochrome P450 (CYP) enzymes, namely cholesterol sidechain cleavage enzyme (CYP11A), 21-hydroxylase (CYP21) and 17 $\alpha$-hydroxylase/17, 20 lyase (CYP17), are targets of adrenal/gonadal antibodies (5-7), although there is no general agreement regarding the main adrenal autoantigen (4). Autoimmunity to pancreatic islet cells and glutamic acid decarboxylase $65-\mathrm{kDa}$ isoform (GAD65) has been observed in many APECED patients, with and without IDDM (4, 8-10). With regard to APECED-associated AIH, CYP1A2 and CYP2A 6 have been identified as targets of liver-kidney microsomal antibodies (LKM-A) (11). In contrast, no previous studies have been performed on APECED patients to establish the prevalence of autoimmunity to other antigens, such as tyrosine phosphatase-like protein IA2, insulin, thyroperoxidase and thyroglobulin, which may be autoantibody targets in their respective autoimmune diseases $(12,13)$.

Here we report the distribution of organ-specific and non-organ-specific autoantibodies in APECED patients living in the Salento region of southern Italy. Interestingly, in addition to several organ-specific autoantibodies, we detected markers of non-organ-specific autoimmunity in almost all subjects.

\section{Subjects and methods}

\section{Subjects}

The presence of organ-specific and non-organ-specific autoantibodies was evaluated in eleven APECED patients from Salento, a geographically delimited region of southern Italy. Seven of the patients originated within a radius of $15 \mathrm{~km}$ of the chief town of the province, Lecce. There were three pairs of siblings (patients 1 and 2, 3 and 4, and 7 and 8). The clinical characteristics of the population studied are summarised in Table 1. Diagnoses of the disease components were made according to Ahonen et al. (3), with the exception of atrophic gastritis, which was diagnosed by supranormal levels of plasma gastrin and endoscopic and microscopic examinations. Of the patients reported as having $\mathrm{AIH}$, patient 6 had sudden severe hypertransaminasaemia (about twelve times the upper normal limit of alanine transaminase, with normal serum alkaline phosphatase) and underwent therapy with prednisone and azathioprine, which was followed by complete response (definite $\mathrm{AIH}$ ); his parents refused a liver biopsy. Patients 2 and 9 had intermittent increase in serum transaminases (up to three times the upper normal limit of alanine transaminase, with normal serum alkaline phosphatase) and persistent hypergammaglobulinaemia, but neither underwent liver biopsy or immunosuppressive therapy (probable AIH) (14). In these three patients, other causes of liver damage were carefully excluded. Sjögren's syndrome was diagnosed according to current criteria (15). Among ectodermal dystrophies, keratitis was present in patient 9, alopecia in patients $1,2,4,9,10$ (areata) and 6 (universalis), vitiligo in patient 6 , and tympanic calcifications in patients 1,5 and 6 . In addition, all the patients had varying degrees of dental enamel hypoplasia. Patients came to our notice at various ages. After initial clinical and laboratory assessment, follow-up was carried out every 3-6 months. If negative, antibodies were periodically re-assayed. If positive, they were further assayed only in the absence of related organ failure.

\section{Immunofluorescence assays}

Antibodies (A) to the parathyroid glands (PT-A), adrenal cortex (AC-A), pancreatic islet cells (IC-A),

Table 1 Clinical features of the patients (numbers in parentheses are the ages at clinical onset of the diseases, in years).

\begin{tabular}{|c|c|c|c|c|c|c|c|c|c|c|c|}
\hline & \multicolumn{11}{|c|}{ Patient } \\
\hline & 1 & 2 & 3 & 4 & 5 & 6 & 7 & 8 & 9 & 10 & 11 \\
\hline Sex & $\mathrm{M}$ & $\mathrm{F}$ & $\mathrm{F}$ & $\mathrm{M}$ & $\mathrm{F}$ & $\mathrm{M}$ & $\mathrm{M}$ & M & $\mathrm{F}$ & $\mathrm{M}$ & $\mathrm{F}$ \\
\hline Age at last examination (years) & 40 & 25 & 36 & 33 & 11 & 14 & 13 & 9 & 22 & 21 & 5 \\
\hline $\mathrm{CMC}$ & $+(1)$ & $+(1)$ & $+(6)$ & $+(1)$ & $+(<1)$ & $+(<1)$ & $+(<1)$ & $+(7)$ & $+(1)$ & $+(13)$ & $+(<1)$ \\
\hline Hypoparathyroidism & $+(17)$ & $+(8)$ & $+(7)$ & $+(2)$ & $+(2)$ & $+(1)$ & $+(<1)$ & $+(8)$ & $+(10)$ & $+(6)$ & $+(1)$ \\
\hline Addison's disease & $+(16)$ & $+(3)$ & - & $+(14)$ & $+(10)$ & $+(13)$ & $+(4)$ & $+(7)$ & $+(3)$ & - & $+(5)$ \\
\hline Hypogonadism & - & $+(23)$ & $+(16)$ & - & $?$ & $?$ & $?$ & $?$ & - & - & $?$ \\
\hline IDDM & - & - & - & - & - & - & - & - & - & - & - \\
\hline Hypothyroidism & - & $+(4)$ & - & - & - & $+(10)$ & $+(11)$ & - & $+(13)$ & - & - \\
\hline Atrophic gastritis & + & $\mathrm{Nd}$ & + & - & - & - & - & - & + & - & - \\
\hline Pernicious anaemia & - & - & - & - & - & - & - & - & $+(22)$ & - & - \\
\hline Autoimmune hepatitis & - & $+(9)$ & - & - & - & $+(13)$ & - & - & $+(21)$ & - & - \\
\hline Malabsorption & - & $+(10)$ & - & - & - & - & - & - & $+(12)$ & - & - \\
\hline Sjögren's syndrome & + & $\mathrm{Nd}$ & + & - & - & - & - & - & - & - & - \\
\hline
\end{tabular}

Nd, not determined. 
ovary at follicular phase and testis (steroid cell antibodies, SC-A), gastric parietal cells (PC-A), smooth muscle (SM-A), and double-stranded DNA (dsDNA-A), as well as LKM-A, anti-mitochondrial (AM-A) and anti-nuclear (AN-A) antibodies, were assessed by indirect immunofluorescence (IF). Monkey substrates were used for PT-A, AC-A, IC-A and SC-A; a rat stomach/liver/kidney substrate for PC-A, SM-A, LKM-A and AM-A; HEp-2 cells for AN-A, and Crithidia luciliae kinetoplast for dsDNA-A. In each assay, thin cryosections $(3-5 \mu \mathrm{m})$ were incubated at room temperature for $30 \mathrm{~min}$ with patient sera starting from 1:10 dilution and with negative and positive controls, washed twice in phosphate-buffered saline (PBS) and incubated at room temperature for $30 \mathrm{~min}$ with fluorescein isothiocyanate-conjugated goat antihuman immunoglobulin (Ig) G (Delta Biologicals, Pomezia, Italy; for LKM-A, Sanofi, Chaska, MN, USA). For analysis of results, Olympus IMT2 (Olympus, Marburg, Germany) and Leitz Orthoplan (Leitz, Wetzlar, Germany) microscopes were used.

\section{Radiobinding and immunoradiometric assays}

Antibodies to CYP11A (CYP11A-A), CYP21 (CYP21A), CYP17 (CYP17-A), GAD65 (GAD65-A) and IA2 (IA2-A) were determined by a radiobinding assay according to previously described procedures (16-18). Briefly, ${ }^{35}$ S-labelled recombinant human autoantigens were produced by in vitro coupled transcription/ translation, and immunoprecipitated with human serum at a 1:25 dilution. The antibody-bound antigen was separated by protein A-sepharose (Pharmacia, Uppsala, Sweden) and the immunoprecipitated radioactivity determined by liquid scintillation. Antibody levels were expressed as relative indices using one positive and two negative standard sera in each assay. Cut-off values were 0.061 for CYP11A-A, CYP21-A and CYP17-A, 0.035 for GAD65-A and 0.040 for IA2-A. Validation of the assays and determination of the upper limits of the normal range by using sera from healthy controls have been extensively reported (16-18). Kind gifts of full-length human complementary DNA for

Table 2 Results of the antibody assays in each patient.

\begin{tabular}{|c|c|c|c|c|c|c|c|c|c|c|c|}
\hline & \multicolumn{11}{|c|}{ Patient } \\
\hline & 1 & 2 & 3 & 4 & 5 & 6 & 7 & 8 & 9 & 10 & 11 \\
\hline PT-A ${ }^{a}$ & $-^{\mathrm{e}}$ & $\mathrm{Nt}$ & $\mathrm{Nt}$ & $\mathrm{Nt}$ & - & $\begin{array}{l}+ \\
1: 40\end{array}$ & - & - & - & - & - \\
\hline$A C-A^{a}$ & $\begin{array}{l}+ \\
1: 10\end{array}$ & $\begin{array}{l}+ \\
1: 20\end{array}$ & $\begin{array}{l}+ \\
1: 20\end{array}$ & $\begin{array}{l}+ \\
1: 20\end{array}$ & $\begin{array}{l}+ \\
1: 20\end{array}$ & $\begin{array}{l}+ \\
1: 20\end{array}$ & $\begin{array}{l}+ \\
1: 160\end{array}$ & $\begin{array}{l}+ \\
1: 80\end{array}$ & $\begin{array}{l}+ \\
1: 10\end{array}$ & $\begin{array}{l}+ \\
1: 10\end{array}$ & $\begin{array}{l}+ \\
1: 80\end{array}$ \\
\hline$S C-A^{a}$ & $\begin{array}{l}+ \\
1: 10\end{array}$ & $\begin{array}{l}+ \\
1: 20\end{array}$ & +4 & $\begin{array}{l}+ \\
1: 20\end{array}$ & $\begin{array}{l}+ \\
1: 40\end{array}$ & $\begin{array}{l}+ \\
1: 20\end{array}$ & $\begin{array}{l}+ \\
1: 40\end{array}$ & +4 & $\stackrel{+}{1: 40}$ & $+\underset{1: 10}{+}$ & $+\underset{1: 80}{+}$ \\
\hline CYP11A-A & $\begin{array}{l}+ \\
0.665\end{array}$ & $\mathrm{Nt}$ & $\begin{array}{l}+ \\
0.654\end{array}$ & $\begin{array}{l}+ \\
0.585\end{array}$ & $\overline{0} .008$ & $\begin{array}{l}+ \\
1.000\end{array}$ & $\begin{array}{l}+ \\
0.428\end{array}$ & $\begin{array}{l}+ \\
0.459\end{array}$ & $\begin{array}{l}+ \\
0.824\end{array}$ & $\begin{array}{l}+ \\
0.110\end{array}$ & $\begin{array}{l}+ \\
0.697\end{array}$ \\
\hline CYP21-A & $\begin{array}{l}+ \\
0.596\end{array}$ & $\mathrm{Nt}$ & 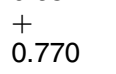 & $\begin{array}{l}+ \\
0.568\end{array}$ & $\stackrel{+}{0.792}$ & $\stackrel{+}{0.768}$ & $\begin{array}{l}+ \\
1.053\end{array}$ & $\begin{array}{l}+ \\
0.724\end{array}$ & -0.009 & $\begin{array}{l}- \\
-0.012\end{array}$ & $\begin{array}{l}+ \\
1.038\end{array}$ \\
\hline CYP17-A & $\begin{array}{l}+ \\
0.186\end{array}$ & $\mathrm{Nt}$ & $\overline{0} .000$ & $\begin{array}{l}+ \\
0.194\end{array}$ & $\begin{array}{l}+ \\
0.254\end{array}$ & $\begin{array}{l}+ \\
0.622\end{array}$ & $\begin{array}{l}- \\
-0.040\end{array}$ & + & $\overline{0} .039$ & $\begin{array}{l}- \\
-0.076\end{array}$ & $\overline{0} .005$ \\
\hline$I C-A^{a}$ & $\stackrel{+}{1: 80}$ & - & $\begin{array}{l}+ \\
1: 10\end{array}$ & - & - & - & - & - & $\begin{array}{l}+ \\
1: 40\end{array}$ & - & - \\
\hline GAD65-A ${ }^{b}$ & $\begin{array}{l}+ \\
0.730\end{array}$ & $\mathrm{Nt}$ & $\overline{0} .022$ & -0.001 & $\overline{0} .021$ & $\overline{0} .013$ & $\overline{0} .019$ & $\begin{array}{l}- \\
-0.029\end{array}$ & $\begin{array}{l}+ \\
1.604\end{array}$ & $\begin{array}{l}+ \\
0.057\end{array}$ & $\begin{array}{l}- \\
-0.009\end{array}$ \\
\hline $\mathrm{IA} 2-\mathrm{A}^{\mathrm{b}}$ & $\begin{array}{l} \pm \\
0.040\end{array}$ & $\mathrm{Nt}$ & $\begin{array}{l}+ \\
2.200\end{array}$ & -0.001 & $\begin{array}{l}- \\
-0.005\end{array}$ & $\overline{0} .002$ & $\overline{0} .017$ & $\overline{0} .017$ & $\begin{array}{l}- \\
-0.003\end{array}$ & $\begin{array}{l}- \\
-0.002\end{array}$ & $\begin{array}{l}- \\
-0.007\end{array}$ \\
\hline TM-A ${ }^{c}$ & $\begin{array}{l}- \\
<50\end{array}$ & $+_{1639}$ & $\begin{array}{l}- \\
<50\end{array}$ & $<50$ & $\begin{array}{l}- \\
<50\end{array}$ & $\begin{array}{l}+ \\
638\end{array}$ & $\begin{array}{l}+ \\
2224\end{array}$ & $\begin{array}{l}- \\
<50\end{array}$ & $\begin{array}{l}+ \\
381\end{array}$ & $\begin{array}{l}- \\
<50\end{array}$ & $\begin{array}{l}- \\
<50\end{array}$ \\
\hline TPO-A ${ }^{d}$ & $\begin{array}{l}- \\
<10\end{array}$ & $\begin{array}{l}+ \\
>1000\end{array}$ & $\begin{array}{l}- \\
<10\end{array}$ & $\begin{array}{l}- \\
<10\end{array}$ & $\begin{array}{l}- \\
<10\end{array}$ & $\stackrel{+}{606}$ & $\begin{array}{l}+ \\
>1000\end{array}$ & $\begin{array}{l}- \\
<10\end{array}$ & $\begin{array}{l}+ \\
271\end{array}$ & $\begin{array}{l}- \\
<10\end{array}$ & $\begin{array}{l}- \\
<10\end{array}$ \\
\hline$T G-A^{c}$ & $\frac{-}{64}$ & $\begin{array}{l}+ \\
>5000\end{array}$ & $\begin{array}{l}+ \\
193\end{array}$ & $\begin{array}{l}+ \\
105\end{array}$ & $\begin{array}{l}- \\
<50\end{array}$ & $\begin{array}{l}- \\
<50\end{array}$ & $\begin{array}{l}+ \\
>5000\end{array}$ & $\begin{array}{l}- \\
<50\end{array}$ & $\frac{-}{58}$ & $\frac{-}{70}$ & $\begin{array}{l}- \\
<50\end{array}$ \\
\hline$P C-A^{a}$ & $\begin{array}{l}+ \\
1: 20\end{array}$ & $\mathrm{Nt}$ & $\begin{array}{l}+ \\
1: 80\end{array}$ & - & - & - & - & - & $\begin{array}{l}+ \\
1: 40\end{array}$ & - & - \\
\hline IFa-A ${ }^{a}$ & $\begin{array}{l}+ \\
1: 25\end{array}$ & $\mathrm{Nt}$ & $\begin{array}{l}+ \\
1: 25\end{array}$ & - & - & - & - & - & $\begin{array}{l}+ \\
1: 25\end{array}$ & - & - \\
\hline $\mathrm{LKM} \mathrm{A}^{\mathrm{a}}$ & - & $\mathrm{Nt}$ & - & - & - & $\begin{array}{l}+ \\
1: 80\end{array}$ & - & - & $\begin{array}{l}+ \\
1: 80\end{array}$ & - & - \\
\hline$A N-A^{a}$ & $\begin{array}{l}+ \\
1: 80\end{array}$ & $\mathrm{Nt}$ & $\begin{array}{l}+ \\
1: 20\end{array}$ & - & $\begin{array}{l}+ \\
1: 40\end{array}$ & $\begin{array}{l}+ \\
1: 20\end{array}$ & $\begin{array}{l}+ \\
1: 20\end{array}$ & $\begin{array}{l}+ \\
1: 40\end{array}$ & $\begin{array}{l}+ \\
1: 80\end{array}$ & $\begin{array}{l}+ \\
1: 40\end{array}$ & $\begin{array}{l}+ \\
1: 80\end{array}$ \\
\hline$E^{2 N A-A^{a}}$ & $\begin{array}{l}\text { SSB/La } \\
1: 150\end{array}$ & $\mathrm{Nt}$ & $\begin{array}{l}\text { SSB/La } \\
1: 150\end{array}$ & - & $\begin{array}{l}\text { SSA/Ro } \\
1: 150\end{array}$ & $\begin{array}{l}\text { SSB/La } \\
1: 150\end{array}$ & $\begin{array}{l}\mathrm{SmB}^{\prime} / \mathrm{B} \\
1: 150\end{array}$ & $\begin{array}{l}\text { RNP A } \\
1: 150\end{array}$ & $\begin{array}{l}\text { SSA/Ro } \\
1: 150\end{array}$ & $\begin{array}{l}\text { SSA/Ro } \\
1: 150\end{array}$ & $\begin{array}{l}\text { SSA/Ro } \\
1: 150\end{array}$ \\
\hline
\end{tabular}

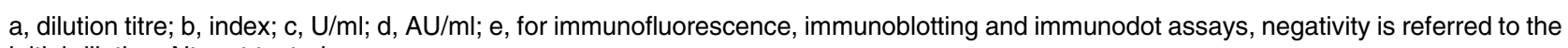
initial dilution; Nt, not tested. 
CYP21 (Dr Bon-Chu Chung, Institute of Molecular Biology, Academia Sinica, Taipei, Taiwan), GAD65 (Dr Åke Lernmark, Department of Medicine, University of Washington, Seattle, WA, USA), IA2 (Dr George S Eisenbarth, Barbara Davis Center for Childhood Diabetes, Denver, CO, USA), and CYP11A and CYP17 (Dr Walter L Miller, Department of Pediatrics, University of California, S Francisco, CA, USA) were received.

Insulin autoantibodies (IA-A) were detected by a radiobinding assay based on patient serum capacity to bind human ${ }^{125}$ I-insulin in comparison with a reference blank (Biodata, Guidonia, Italy); samples having a value higher than three times that of the reference blank were considered positive.

Thyroid microsomal (TM-A), thyroperoxidase (TPOA) and thyroglobulin (TG-A) antibodies were assessed by immunoradiometric assay (IRMA), using ${ }^{125} \mathrm{I}-$ labelled protein A (TM-A and TG-A from Radim, Pomezia, Italy; TPO-A from Sorin, Saluggia, Italy). Samples were positive if the antibody value was higher than $100 \mathrm{U} / \mathrm{ml}$ (TM-A and TG-A), or $10 \mathrm{AU} / \mathrm{ml}$ (TPO-A), where AU was an arbitrary value related to a reference antibody preparation. Thyrotropin-receptor antibodies (TR-A) were assayed by IRMA utilising ${ }^{125}$ I-thyrotrophin (Brahms, Berlin, Germany). Cut-off was $18 \mathrm{U} / \mathrm{l}$.

\section{Immunoblotting assays}

Identification of antibodies to extractable nuclear antigens was performed by immunoblotting utilising the following antigens from HeLa cells: $\mathrm{SmB}^{\prime} / \mathrm{B}$ and SmD, 70-kDa RNP, RNP A and RNP C, 60-kDa and 52$\mathrm{kDa}$ SSA/Ro, plus occasional 40-kDa, 34-kDa and 33$\mathrm{kDa}$ SSA/Ro epitopes (deriving from the major SSA/Ro antigens), 48-kDa SSB/La, Scl-70, Jo-1 and Rib P0 (ribosomal phosphoprotein P0). In this test the antigens, separated by electrophoresis, are fixed onto strips which also contain internal reference with five precoloured calibration bands. Briefly, patient sera diluted 1:150 and negative and positive controls were incubated with the strips for $15 \mathrm{~min}$ at room temperature with gentle agitation; the strips were rinsed and bound antibodies were identified with peroxidase-conjugated rabbit anti-human IgG and IgM (Delta Biologicals). The appearance of blue bands and their position allowed autoantibody identification.

Liver microsomal, mitochondrial and soluble protein fractions were obtained from liver homogenate by differential centrifugation and ultracentrifugation as previously described (11), while microsomes from human B-lymphoblastoid cells expressing recombinant CYP1A2, CYP2A6, CYP2C9, CYP2D6, CYP2E1 and CYP3A4 were purchased from Gentest Co. (Woburn, MA, USA). For Western blotting, the protein fractions and recombinant CYPs were separated on a $10 \%$ polyacrylamide gel under denaturing and non-denaturing conditions, and were transferred onto nitrocellulose filters. After blockage for $1 \mathrm{~h}$ in PBS, $0.1 \%$ Tween 20 and 5\% non-fat dry milk solution, and incubation for $1 \mathrm{~h}$ at room temperature with patient sera at 1:100 dilution, the filters were incubated for $1 \mathrm{~h}$ at room temperature with a 1:1000 dilution of alkaline phosphatase-conjugated goat anti-human IgG, IgM and IgA (ICN Biomedicals, Aurora, OH, USA). The blots were developed using the nitroblue tetrazolium chloride/5bromo-4-chloro-3-indolyl phosphate detection system (Promega, Madison, WI, USA).

Intrinsic factor antibodies (IFa-A) were detected by an immunodot assay using highly purified intrinsic factor from porcine gastric mucosa dotted on nitrocellulose membrane strips (Alifax, Padua, Italy); in the test, serum samples were diluted 1:25 with PBS.

\section{Results}

The results are detailed in Table 2 . In the case of two or more measurements, the highest positivity is reported. In patient 2, not all assays were performed (the patient died at the age of 27 of oral carcinoma).

All the patients were positive for AC-A and SC-A. Among the ten patients who were assayed for antibodies to adrenal/gonadal CYP enzymes, CYP11A-A were found in nine patients, CYP21-A in eight, and CYP17$A$ in five. In particular, patients 5, 6, 7, 8 and 11, who had Addison's disease of short-medium duration $(<15$ years), were all positive for CYP21-A, while CYP11A-A were absent in patient 5 , and CYP17-A were absent in patients 7 and 11; in addition, patient 5 had positivity only for AC-A and CYP21-A at the time of adrenal failure onset; she underwent a re-assay for CYP11A-A and CYP17-A after the appearance of SC-A reactivity ten months later, and she tested positive for CYP17-A. Of the three patients with Addison's disease of long duration ( $>15$ years), patients 1 and 4 were positive for all three CYP antibodies, while patient 9 tested positive for CYP11A-A. Patient 3 was positive for CYP11A-A and CYP21-A, and patient 10 for CYP11A-A; these two patients showed neither clinical nor laboratory signs of adrenocortical impairment according to the standard criteria (3). While patient 10 had a three-year follow-up during which his adrenocortical function remained normal, follow-up of patient 3 has only just started.

In the IF assay for SC-A, ovary theca cells were clearly stained in patients $4,6,7,8$ and 11 ; in these patients, a faint reaction with granulosa cells was also seen. Sera from patients 1, 3 and 9 strongly stained both theca and granulosa cells. In patient 5 only a weak reaction with theca cells was visible, while serum from patient 10 furnished a weak but diffuse staining. Of the subjects below 15 years of age, only patient 6 had signs of puberty onset (stage 2).

Patients 1 and 9 had positivity for IC-A and GAD65-A (patient 1 also had a borderline value for IA2-A), while IC-A and IA2-A were detected in patient 3; a slight positivity for GAD65-A was seen in patient 10. Fasting $\mathrm{C}$-peptide measured by immunoenzymometric assay 
(Eurogenetics, Rivoli, Italy) showed no statistical difference between these four subjects and the others (mean \pm s.D., $2.47 \pm 1.69$ vs $2.99 \pm 1.97 \mu \mathrm{g} / \mathrm{l}$ ). All four hypothyroid patients were positive for TM-A and TPO$\mathrm{A}$, and two of them were also positive for TG-A. In patients 3 and 4, who were euthyroid, only TG-A were detected. Patients 1, 3 and 9 had positivity for PC-A and IFa-A, and evidence of atrophic gastritis, but only patient 9, who had associated malabsorption, developed pernicious anaemia. In IF on liver and kidney sections, patients 6 and 9 showed LKM-A immunostaining. A positive reaction against the microsomal $51-\mathrm{kDa}$ protein band of CYP2A 6 was observed with both patient sera only in Western blotting experiments performed under non-denaturing conditions.

All patients but one were positive for AN-A. In all sera a speckled pattern was seen; in the sample from patient 7 , some nuclei gave a homogeneous pattern. However, only patients 1 and 3 fulfilled the diagnostic criteria for a connective tissue disease (Sjögren's syndrome). The percentage of healthy subjects who in our laboratory routinely test positive for AN-A on HEp- 2 cells does not exceed $5 \%$ of children of either sex at a 1:20 serum dilution, and $10 \%$ of adults at a $1: 40$ serum dilution. There is no substantial variation across subgroups spanning 20-60 years of age, but there is a higher prevalence in women (male/female sex ratio about 1:2). Target antigens of the AN-A positive sera were: SSB/La in patients 1, 3 and 6; 52-kDa SSA/Ro in patient 5; $\mathrm{SmB}^{\prime} / \mathrm{B}$ in patient 7 ; RNP A in patient $8 ; 40-\mathrm{kDa}$ and 34-kDa SSA/Ro in patients 9 and 10, and 60-kDa in patient 11. SM-A, AM-A, dsDNA-A, IA-A and TR-A were negative in all tested patients (not shown in Table 2).

\section{Discussion}

AIRE encodes for a 545 amino acid protein, which contains two PHD-finger motifs and other sequences common to transcription factors $(1,19)$. It has been hypothesised that AIRE plays a role in the induction of self-tolerance, perhaps acting as co-activator of nuclear receptors involved in the process of clonal deletion: the defective apoptosis of self-reactive T cells would represent the pathogenesis of the disease (20). It is suggestive that messenger RNA for AIRE is prevalent in the thymus, adrenal cortex and pancreas (1). While CMC is the most evident result of defective T-cell function, autoantibodies to the adrenal cortex and pancreatic islet cells are among those most frequently detected in APECED patients.

It is well known that autoimmunity to adrenal cortex and gonads targets some steroidogenic enzymes; nevertheless identifying the major autoantibody target in APECED-related Addison's disease has been a somewhat controversial issue (4). Some initial reports indicated CYP17 (21), CYP11A (22), or both (23) as the adrenalspecific antigens in APECED. Apart from the prevalence of each autoantibody, other studies have found that CYP2 1 is the major antigen in autoimmune Addison's disease regardless of whether it occurs as isolated failure or in polyglandular syndromes $(4-6,18,24)$. All our patients with adrenal failure of short-medium duration were positive for CYP21-A, while CYP11A-A were absent in patient 5 , and CYP17-A were absent in patient 5 at the time of disease onset, and in patients 7 and 11 . In addition, patient 10, who had isolated positivity for CYP11A-A, showed no signs of adrenocortical impairment throughout our follow-up. The negativity for CYP21-A in patient 9 may be explained by the duration of Addison's disease, which in several cases correlates inversely with AC-A and CYP21-A levels (24).

On the other hand, all sera showed the presence of CYP11A-A and/or CYP17-A, which have been found to be major components of SC-A (4-7). As previously signalled (5), pronounced differences in the intensity of reaction with ovary theca and granulosa cells were seen even between patients having the same antibody pattern. Prepubertal ages of patients 5, 6, 7, 8 and 11 made it impossible to match the prevalence of hypogonadism with the positivity for SC-A and related CYP antibodies: previous studies have shown that these markers correlate significantly to gonadal failure only in female patients $(4,5)$.

Positivity for IC-A and GAD65-A is not infrequent in APECED patients: lower fasting C-peptide and first phase insulin response have been found more often in patients with GAD65-A than in those without (9). Three of our patients were IC-A positive, two of them with associated positivity for GAD65-A, and the other for IA2-A. There are no prospective studies on the development of IDDM in APECED patients having humoral markers of islet cell autoimmunity and/or laboratory signs of decreased insulin secretory capacity; however the low prevalence of IDDM in APECED suggests that such conditions lead to overt $\beta$-cell failure in a limited number of subjects ( 3 , $4,9)$. This hypothesis is supported by studies on patients with unselected autoimmune polyendocrinopathies (25); if present, metabolic deterioration is generally slow (26). On the other hand, no previous studies have been performed to assess the prevalence of IA2-A in APECED patients; it is important to remember that IA2 is a protein homologous to tyrosine phosphatases, and IA2-A contribute substantially to IC-A reactivity (12). Moreover, IA2-A are associated with rapid progression to IDDM (27).

All our hypothyroid patients were TM-A and TPO-A positive, but only two of them were also TG-A positive. In addition, two euthyroid subjects tested positive for TG-A, but we have no information about duration of this condition. While TPO-A are involved in complement-mediated injury and antibody-dependent cellmediated cytotoxicity (13), it is still unclear whether TG-A express real pathogenicity (28). However, these antibodies have not been extensively studied in APECED patients (4), and thus further observations are needed. 
Two out of the three AIH patients were investigated and were positive for the presence of LKM-A. As previously described in Sardinian APECED patients (11), LKM-A reacted with the CYP2A6. However, the sera from our patients reacted only in Western blotting performed under non-denaturing conditions, suggesting that conformational epitopes are predominantly involved.

The observation that some APECED patients suffer from Sjögren's syndrome or other connective tissue diseases, such as rheumatoid arthritis, scleroderma and cutaneous vasculitis $(3,4)$, formed the rationale for appropriate investigations in this field. All but one of the tested patients were AN-A positive, although at low titre, and the SSA/SSB antigen system was mainly involved in this reactivity. However, only patients 1 and 3 were affected by a connective tissue disorder (Sjögren's syndrome). AN-A have not been investigated in the largest studies of APECED patients; thus, we have reviewed 47 articles reporting from one to four APECED cases: AN-A testing was performed on 18 patients (2940 ), of whom five were positive, but most authors failed to provide the method, substrate and dilutions used. It is important to remember that $\mathrm{AN}-\mathrm{A}$ can be found in healthy adults, although varying percentages have been reported (41-43). Positivity is less frequent in children, even using lower serum dilutions $(42,44)$. Again, HEp2 cells are more sensitive in AN-A detection than rat sections $(42,44)$. On the other hand, AN-A are frequently positive in patients suffering from IDDM, thyroid diseases or other autoimmune disorders (2).

In summary, autoantibodies detectable in each APECED patient are the best evidence of deep abnormality in the immune system. Although their role in organ damage is not clear (2), autoantibodies remain valuable markers of disease, especially at the onset of organ failure. Our findings are in agreement with most data previously recorded in APECED patients, and are consistent with the hypothesis that non-organ-specific antibodies contribute to autoimmunity in this syndrome.

\section{Acknowledgements}

The authors are indebted to Mr George Metcalf, University of Lecce, for his help in translating the manuscript.

\section{References}

1 The Finnish-German APECED Consortium. An autoimmune disease, APECED, caused by mutations in a novel gene featuring two PHD-type zinc-finger domains. Nature Genetics 199717 399-403.

2 Trence DL, Morley JE \& Handwerger BS. Polyglandular autoimmune syndromes. American Journal of Medicine 198477 107116.

3 Ahonen P, Myllärniemi S, Sipilä I \& Perheentupa J. Clinical variation of autoimmune polyendocrinopathy-candidiasis-ectodermal dystrophy (APECED) in a series of 68 patients. New England Journal of Medicine 1990322 1829-1836.

4 Betterle C, Greggio NA \& Volpato M. Autoimmune polyglandular syndrome type 1. Journal of Clinical Endocrinology and Metabolism 199883 1049-1055.

5 Uibo R, Aavik E, Peterson P, Perheentupa J, Aranko S, Pelkonen R et al. Autoantibodies to cytochrome P450 enzymes P450scc, $\mathrm{P} 450 \mathrm{c} 17$, and P450c21 in autoimmune polyglandular disease types I and II and in isolated Addison's disease. Journal of Clinical Endocrinology and Metabolism 199478 323-328.

6 Chen S, Sawicka J, Betterle C, Powell M, Prentice L, Volpato M et al. Autoantibodies to steroidogenic enzymes in autoimmune polyglandular syndrome, Addison's disease, and premature ovarian failure. Journal of Clinical Endocrinology and Metabolism 199681 1871-1876.

7 Peterson P, Uibo R, Peränen J \& Krohn K. Immunoprecipitation of steroidogenic enzyme autoantigens with autoimmune polyglandular syndrome type I (APS I) sera; further evidence for independent humoral immunity to P450c17 and P450c21. Clinical and Experimental Immunology 1997107 335-340.

8 Velloso LA, Winqvist O, Gustafsson J, Kämpe O \& Karlsson FA. Autoantibodies against a novel $51 \mathrm{kDa}$ islet antigen and glutamate decarboxylase isoforms in autoimmune polyendocrine syndrome type I. Diabetologia 199437 61-69.

9 Tuomi T, Björses P, Falorni A, Partanen J, Perheentupa J, Lernmark $\AA$ et al. Antibodies to glutamic acid decarboxylase and insulin-dependent diabetes in patients with autoimmune polyendocrine syndrome type I. Journal of Clinical Endocrinology and Metabolism 199681 1488-1494.

10 Sanjeevi CB, Falorni A, Robertson J \& Lernmark A. Glutamic acid decarboxylase (GAD) in insulin-dependent diabetes mellitus. Diabetes, Nutrition and Metabolism 19969 167-182.

11 Clemente MG, Meloni A, Obermayer-Straub P, Frau F, Manns MP \& De Virgiliis S. Two cytochromes P450 are major hepatocellular autoantigens in autoimmune polyglandular syndrome type 1. Gastroenterology $1998114324-328$.

12 Kawasaki E \& Eisenbarth GS. Multiple autoantigens in the prediction and pathogenesis of type I diabetes. Diabetes, Nutrition and Metabolism 19969 188-198.

13 Weetman AP \& McGregor AM. Autoimmune thyroid disease: further developments in our understanding. Endocrine Reviews $199415788-830$.

14 Johnson PJ \& McFarlane IG. Meeting report: International Autoimmune Hepatitis Group. Hepatology 199318 998-1005.

15 Vitali C, Bombardieri S, Moutsopoulos HM, Balestrieri G, Bencivelli W, Bernstein RM et al. Preliminary criteria for the classification of Sjögren's syndrome. Arthritis and Rheumatism $199336340-347$.

16 Falorni A, Nikoshkov A, Laureti S, Grenbäck E, Hulting A-L, Casucci G et al. High diagnostic accuracy for idiopathic Addison's disease with a sensitive radiobinding assay for autoantibodies against recombinant human 21-hydroxylase. Journal of Clinical Endocrinology and Metabolism $1995802752-2755$.

17 Falorni A, Örtqvist E, Persson B \& Lernmark A. Radioimmunoassays for glutamic acid decarboxylase (GAD65) and GAD65 autoantibodies using ${ }^{35} \mathrm{~S}$ or ${ }^{3} \mathrm{H}$ recombinant human ligands. Journal of Immunological Methods 1995186 89-99.

18 do Carmo Silva R, Kater CE, Dib SA, Laureti S, Forini F, Cosentino A et al. Autoantibodies against recombinant human steroidogenic enzymes 21-hydroxylase, side-chain cleavage and $17 \alpha$-hydroxylase in Addison's disease and autoimmune polyendocrine syndrome type III. European Journal of Endocrinology 2000142 187-194.

19 Gibson TJ, Ramu C, Gemünd C \& Aasland R. The APECED polyglandular autoimmune syndrome protein, AIRE-1, contains the SAND domain and is probably a transcription factor. Trends in Biochemical Sciences 199823 242-244.

20 Peterson P, Nagamine K, Scott H, Heino M, Kudoh J, Shimizu N et al. APECED: a monogenic autoimmune disease providing new clues to self-tolerance. Immunology Today 199819 384-386. 
21 Krohn K, Uibo R, Aavik E, Peterson P \& Savilahti K. Identification by molecular cloning of an autoantigen associated with Addison's disease as steroid $17 \alpha$-hydroxylase. Lancet $1992339770-773$.

22 Winqvist O, Gustafsson J, Rorsman F, Karlsson FA \& Kämpe O. Two different cytochrome $\mathrm{P} 450$ enzymes are the adrenal antigens in autoimmune polyendocrine syndrome type I and Addison's disease. Journal of Clinical Investigation 199392 2377-2385.

23 Uibo R, Perheentupa J, Ovod V \& Krohn KJE. Characterization of adrenal autoantigens recognized by sera from patients with autoimmune polyglandular syndrome (APS) type I. Journal of Autoimmunity 19947 399-411.

24 Falorni A, Laureti S, Nikoshkov A, Picchio ML, Hallengren B, Vandewalle CL et al. 21-Hydroxylase autoantibodies in adult patients with endocrine autoimmune diseases are highly specific for Addison's disease. Clinical and Experimental Immunology 1997 107 341-346.

25 Bosi E, Becker F, Bonifacio E, Wagner R, Collins P, Gale EAM et al. Progression to type I diabetes in autoimmune endocrine patients with islet cell antibodies. Diabetes $199140977-984$.

26 Wagner R, Genovese S, Bosi E, Becker F, Bingley PJ, Bonifacio E et al. Slow metabolic deterioration towards diabetes in islet cell antibody positive patients with autoimmune polyendocrine disease. Diabetologia 199437 365-371.

27 Christie MR, Genovese S, Cassidy D, Bosi E, Brown TJ, Lai M et al. Antibodies to islet $37 \mathrm{k}$ antigen, but not to glutamate decarboxylase, discriminate rapid progression to IDDM in endocrine autoimmunity. Diabetes 199443 1254-1259.

28 Tomer Y. Anti-thyroglobulin autoantibodies in autoimmune thyroid diseases: cross-reactive or pathogenic? Clinical Immunology and Immunopathology 199782 3-11.

29 Drury MI, Keelan DM, Timoney FJ \& Irvine WJ. Juvenile familial endocrinopathy. Clinical and Experimental Immunology 19707 125-132.

30 Stankler L \& Bewsher PD. Chronic mucocutaneous candidiasis, endocrine deficiency and alopecia areata. British Journal of Dermatology $197286238-245$.

31 Arvanitakis C \& Knouss RF. Selective hypopituitarism. Impaired cell-mediated immunity and chronic mucocutaneous candidiasis Journal of the American Medical Association $19732251492-1495$.

32 Conte N, Del Prete GF, Betterle C, Bottazzo GF \& Trisotto A. Familial chronic idiopathic hypoparathyroidism associated with rheumatoid arthritis. Folia Allergologica et Immunologica Clinica $197421482-491$

33 Kaffe S, Petigrow CS, Cahill LT, Perlman D, Moloshok RE, Hirschhorn $\mathrm{K}$ et al. Variable cell-mediated immune defects in a family with 'Candida endocrinopathy syndrome'. Clinical and Experimental Immunology $197520397-408$.
34 Del Prete GF, Bottazzo GF, Betterle C, Bersani G \& Trisotto A. Poliendocrinopatia autoimmune. Studio immunologico. Folia Allergologica et Immunologica Clinica 197522 123-129.

35 Eisenbarth GS, Wilson PW, Ward F, Buckley C \& Lebovitz H. The polyglandular failure syndrome: disease inheritance, HLA type, and immune function. Annals of Internal Medicine $197991528-$ 533.

36 Arulanantham K. Dwyer JM \& Genel M. Evidence for defective immunoregulation in the syndrome of familial candidiasis endocrinopathy. New England Journal of Medicine 1979300 164-168.

37 Delambre C, Teillac D, Brauner R \& De Prost Y. Polyendocrinopathie auto-immune et candidose mucocutanée chronique. Annales de Dermatologie et de Vénéréologie 1989116 117-121.

38 Mandel M, Etzioni A, Theodor R \& Passwell JH. Pure red cell hypoplasia associated with polyglandular autoimmune syndrome type I. Israel Journal of Medical Sciences $198925138-141$.

39 Bereket A, Lowenheim M, Blethen SL, Kane P \& Wilson TA. Intestinal lymphangiectasia in a patient with autoimmune polyglandular disease type I and steatorrhea. Journal of Clinical Endocrinology and Metabolism 199580 933-935.

40 Grossi A, Nozzoli C, Gheri R, Santini V, Marrani C, Zoccolante A et al. Pure red cell aplasia in autoimmune polyglandular syndrome with T lymphocytosis. Haematologica 199883 10431056.

41 de Vlam K, De Keyser F, Verbruggen G, Vandenbossche M, Vanneuville B, D'Haese D et al. Detection and identification of antinuclear autoantibodies in the serum of normal blood donors. Clinical and Experimental Rheumatology 199311 393-397.

42 Forslid J, Heigl Z, Jonsson J \& Scheynius A. The prevalence of antinuclear antibodies in healthy young persons and adults, comparing rat liver tissue sections with HEp-2 cells as antigen substrate. Clinical and Experimental Rheumatology 199412 137141 .

43 Tan EM, Feltkamp TEW, Smolen JS, Butcher B, Dawkins R, Fritzler MJ et al. Range of antinuclear antibodies in 'healthy' individuals. Arthritis and Rheumatism 199740 1601-1611.

44 Arroyave CM, Giambrone MJ, Rich KC \& Walaszek M. The frequency of antinuclear antibody (ANA) in children by use of mouse kidney (MK) and human epithelial cells (HEp-2) as substrates. Journal of Allergy and Clinical Immunology $1988 \mathbf{8 2}$ $741-744$.

Received 28 January 2000

Accepted 3 July 2000 